\title{
Oncocytic Adenoma
}

National Cancer Institute

\section{Source}

National Cancer Institute. Oncocytic Adenoma. NCI Thesaurus. Code C3759.

A benign neoplasm composed of large cells with abundant eosinophilic granular

cytoplasm. Representative examples include oncocytic adenomas of the thyroid gland, parathyroid gland, and pituitary gland. 